\title{
Chlorophyll fluorescence and stomatal conductance of ten sugarcane varieties under waterlogging and fluctuation light intensity
}

\author{
Mochamad Arief Soleh*, Mira Ariyanti, Intan Ratna Dewi, Muhamad Kadapi \\ Faculty of Agriculture, Padjadjaran University, Jalan Raya Bandung-Sumedang km 21, Jatinangor 45363, Indonesia
}

\section{A B S TR A C T}

\begin{abstract}
Under natural conditions, plants are often subjected to waterlogging due to poor soil drainage and or exessive rainfall. This condition leads to reduced maximum quantum yield of photosystem II $\left(\mathrm{f}_{v} / \mathrm{f}_{\mathrm{m}}\right)$ under suboptimal growing system. Under well-watered conditions $(\mathrm{WW})$, the $\mathrm{f}_{\mathrm{v}} / \mathrm{f}_{\mathrm{m}}$ of ten varieties of sugarcane were maintained at more than 0.78 . However, following waterlogging for 4 days and a constant light of $3000 \mu \mathrm{molmol}^{-1}$ for $60 \mathrm{~s}$, the $\mathrm{f}_{\mathrm{v}} / \mathrm{f}_{\mathrm{m}}$ of ten varieties of sugarcene varied from 0.587 in PS882 (V4) to 0.740 in GMP2 (V9). Meanwhile, under fluctuating light intensity from dark to highlight of $1600 \mu \mathrm{molmol}^{-1}$, the $\mathrm{f}_{\mathrm{v}} / \mathrm{f}_{\mathrm{m}}$ of all varieties decreased to below of 0.1 except in the genotype PSJK922 (V5) at 28 DAT (day after treatment) of waterlogging. This difference was then further examined through measurements of stomatal conductance $\left(\mathrm{g}_{\mathrm{s}}\right)$ among the varieties. There was negative correllation between $\mathrm{f}_{\mathrm{v}} / \mathrm{f}_{\mathrm{m}}$ and stomatal conductance, high $\mathrm{g}_{\mathrm{s}}$ was not associated with lower $\mathrm{f}_{\mathrm{v}} / \mathrm{f}_{\mathrm{m}}$. Dendrogam analyses showed the variety of PS881 (V1), PS864 (V3) and Kidang Kencana (KK) were highly sensitive to waterlogging. These results suggest potential screening of plants based on improve $f_{v} / f_{m}$ under abiotic condition.
\end{abstract}

Keywords: Sugarcane; $\mathrm{f}_{\mathrm{v}} / \mathrm{f}_{\mathrm{m}}$; Light intensity; Waterlogging; Stomatal dynamics

\section{INTRODUCTION}

Waterlogging in the field is a major problem in agriculture across the world. Moreover, the IPCC (Intergovernmental Panel for Climate Change) in 2014 has reported that climate change might affect the spatial distribution of rainfall. In some places heavy rainfall may occur frequently, however, at the other places rainfall occurs sporadic. The presence of excessive water due to heavy rainfall accompanied by poor soil drainage system can cause plant stress due to present of hypoxia (Araki et al., 2012), moreover oxygen diffusion into soil decreases up to 320,000 times when soil pores are filled by water than by gas (Armstrong and Drew, 2002; Colmer and Flowers, 2008).

Crop performance under waterlogging stress decreases in vegetative organ, tiller number and yield of wheat (Kozlowski, 1984; Davies \& Hillman, 1988; Huang et al., 1994; Dickin \& Wright, 2008), sugarcane (Singels et al., 2010; Silva et al., 2014) and even decreases physiological performance i.e. photosynthesis, respiration, transpiration and translocation (Else et al., 2001). Besides water stress, crops are always subjected to other abiotic stresses such as light fluctuation from low to high light that may aggravate crop stress. Excess light may decrease maximum quantum yield of photosystem II $\left(\mathrm{f}_{\mathrm{v}} / \mathrm{f}_{\mathrm{m}}\right)$ leading to photo-inhibition of crop (Ksas et al., 2015).

Light fluctuates due to passing clouds, canopy cover and change in leaf angle, this light fluctuation decreases photosynthetic induction response leading to reduce cumulative $\mathrm{CO}_{2}$ fixation (Soleh et al., 2017; Slattery et al., 2018). Non-steady state photosynthesis may be accompanied by differences in the $\mathrm{f}_{\mathrm{v}} / \mathrm{f}_{\mathrm{m}}$, moreover, it is little to know of dynamic $f_{v} / f_{m}$ response under fluctuation light intensity and stressful condition which may affect photosynthesis of non steady state. Light photon is absorbed by chlorophyll then re-emitted partly as fluorescence (Maxwell \& Johnson, 2000), so that the fluorescence could describe plant health particularly in plants exposed to stressful condition. Besides gas exchange measurement, chlorophyll fluorescence induction is one of

\footnotetext{
*Corresponding author:

Mochamad Arief Soleh, Faculty of Agriculture, Padjadjaran University, Jalan Raya Bandung-Sumedang km 21, Jatinangor 45363, Indonesia. Tel: +62 22 779-7321, Fax: +62 22 779-6316, E-mail: m.arief@unpad.ac.id
}

Received: 11 July 2018; $\quad$ Accepted: 28 October 2018 
powerful tools for measuring plant stresses (Lazár 1999, 2006) and indirectly it could provide useful information of leaf photosynthetic performance (Baker and Rosenqvist, 2004). Nowadays, crop physiological performance of crop e.g. photosynthesis and fluorescence are mostly examined under steady state, whereas, crop are always facing dynamic abiotic factors such as light and water.

Another response that is correlated with abiotic stress such as waterlogging is rate of stomatal conductance. Stomatal closure reported had declined $\mathrm{f}_{\mathrm{v}} / \mathrm{f}_{\mathrm{m}}$ (Lawlor \& Cornic, 2002), there was reported decreasing stomatal conductance of seashore mallow to $27 \%$ under waterlogging (Zhou et al., 2012). Nevertheless, stomatal closures did not correlate to $\mathrm{f}_{\mathrm{v}} / \mathrm{f}_{\mathrm{m}}$ under mild drought conditions (Baker and Rosenqvist, 2004). While, fluctuation light intensity will be affected on rapid stomatal opening leading to affected on photosynthesis, there was 10-15\% limitation of photosynthesis across several C3 and C4 species were due to lag time to reach steady state from low to high light (McAusland et al., 2016). Furthermore, the study of growth and physiological traits of sugarcane varieties subjected to light intensity and waterlogging using cluster analysis to reveal correlation among traits under stress condition is one useful method for breeders and agronomist to better understand physiological changes during growth and development stage of sugarcane varieties grown on stress condition. This method reported was successfully differentiated the ability of rice in salinity condition into 4 groups (Chunthaburee et al., 2016) and in Arabidopsis shows distinctive under multiple stress condition (Sawelam et al., 2014)

This study was to evaluate dynamic $\mathrm{f}_{\mathrm{v}} / \mathrm{f}_{\mathrm{m}}$ of ten varieties of sugarcane that were grown under waterlogging stress with exposure to light fluctuation from low to highlight. Furthermore, evaluation of crop performance under dynamic environmental condition i.e. fluctuation light is still needed to be explored. It is very rare information of plant performance evaluated under combined stressful condition of waterlogging and fluctuation light intensity.

\section{MATERIALS AND METHODS}

\section{Plant materials}

Ten sugarcane varieties derived from various origin were chosen: one local variety: Kidang Kencana (KK), seven derived from Indonesian Sugar Research Institute: PS881 (V1), PS862 (V2), PS864 (V3), PS882 (V4), PSJK922 (V5), PSJT941 (V6), and PS921 (V7), and two derived from private sugar company: GMP1 (V8) and GMP2 (V9).

\section{Plant growth place}

The ten varieties were grown in the plastic pot with size of $25 \times 25 \times 50 \mathrm{~cm}$ and grown one seedling per pot.
Row spacing between pots were $70 \times 70 \mathrm{~cm}$. Unsterilized field soil (Fluventic Eutrudepts) was used for growing medium, and NPK fertilizer was added $20 \mathrm{~g}$ per pot. Pots of WW (well watered) and WL (waterlogging) were placed in the field of experimental station of Faculty of Agriculture, Padjadjaran University on April to October 2017 (655`13"S 10746`24"E, 740 m altitude). Waterlogging (WL) treatment pots were placed into small pond to keep plants watered during the experiment. There were 6 pots for each variety under WL treatment.

\section{Chlorophyll fluorescence measurement $\left(f_{v} / f_{m}\right)$}

The $f_{v} / f_{m}$ represents maximum quantum yield of photosystem II (PSII) where the variable fluorescence $\left(\mathrm{f}_{\mathrm{v}}\right)$ is the difference between the maximum $\left(\mathrm{f}_{\mathrm{m}}\right)$ and minimum $\left(f_{\mathrm{o}}\right)$ fluorescence emission in dark-adapted leaves (Kitajima \& Butler 1975). Fluorescence induction was measured by using Handy PEA fluorometer (Hansatech Instruments ltd.) when plants were subjected to waterlogging condition for 2, 4, and 7 DAT (days after treatment) at the vegetative stage (1.5 month old). The measurements were made on $2^{\text {nd }}$ leaf from the uppermost expanded for each genotype. During the measurement, leaves were subjected to dark adaptation for 5-10 min then subjected to highlight of $1500 \mu \mathrm{mol} \mathrm{m}^{-2} \cdot \mathrm{s}^{-1}$ in normal measurement, while measurement of fluctuation light intensity leaves were subjected to various light intensity from low to highlight of $50,100,200,800$, and $1600 \mu \mathrm{mol} \mathrm{m} \mathrm{m}^{-2} \cdot \mathrm{s}^{-1}$ for $1 \mathrm{~min}$ respectively then subjected to $3000 \mu \mathrm{mol} \mathrm{m}^{-2} \cdot \mathrm{s}^{-1}$ at $28 \mathrm{DAT}$. For further analyses of $\mathrm{f}_{\mathrm{v}} / \mathrm{f}_{\mathrm{m}}$, we made regression analysis of $f_{v} / f_{m}$ and $g_{s}$ at 4 DAT of waterlogging treatments.

\section{Stomatal conductance measurement}

Stomatal conductance was measured by using a LeafPorometer (Decagon Devices Inc., USA); three to four plants for each genotype were measured. The measurement was conducted at 2, 4, and 7 DAT or at the vegetative stage (1.5 month old), conducted before noon at the sunny day using the same leaf as $\mathrm{f}_{\mathrm{v}} / \mathrm{f}_{\mathrm{m}}$ measurement.

\section{Root weight and volume}

At the 85 DAT, all varieties were sampled destructively to evaluate root weight and volume. Plants were separated by shoot and root destructively, then root weight and volume measured by using laboratory balance and measuring cylinder respectively (Harrington et al., 1994).

\section{Relationship between $f_{v} / f_{m}$ and $g_{s}$ and Dendogram} Regression analyses of $g_{s}$ and $f_{v} / f_{m}$ were made to show relationship of both parameters. In addition dendrogram analyses was made at 7 DAT across $g_{s}$, and at 85 DAT across panicle number (data not shown) and root volume of tens varieties by ward's method. 


\section{Statistical analyses}

The experimental design was a randomized block design, the measurements were conducted for 3-4 plants for each genotype and then averaged, followed by LSD-Tukey tests. All data were analysed using JMP program (SAS Institute, 2000).

\section{RESULTS}

Before treatment of waterlogging $(0 \mathrm{DAT})$, the $\mathrm{f}_{\mathrm{v}} / \mathrm{f}_{\mathrm{m}}$ of ten sugarcane varieties ranged from 0.8 in $\mathrm{V} 3$ to 0.9 in V9 (Fig. 1A), while $\mathrm{f}_{\mathrm{v}} / \mathrm{f}_{\mathrm{m}}$ after the treatment at $4 \mathrm{DAT}$ ranged from 0.6 in $\mathrm{KK}$ to 0.8 in $\mathrm{V} 1, \mathrm{f}_{\mathrm{v}} / \mathrm{f}_{\mathrm{m}}$ value of KK was significantly lower compared to other varieties except to V2 and V3 (Fig. 1B). Chlorophyll fluorescence measurement $\left(\mathrm{f}_{\mathrm{v}} / \mathrm{f}_{\mathrm{m}}\right)$ at 7 DAT generally had slightly increased again compared to $4 \mathrm{DAT}$. The value of $\mathrm{f}_{\mathrm{v}} / \mathrm{f}_{\mathrm{m}}$ ranged from 0.6 in V3 to 0.8 in V1 and showed significantly different in both varieties of V3 and V1 (Fig. 1C). While, $\mathrm{f}_{\mathrm{v}} / \mathrm{f}_{\mathrm{m}}$ of plants under fluctuation light intensity of dark adaptation from low of $50 \mu \mathrm{mol} \mathrm{m}^{-2} \cdot \mathrm{s}^{-1}$ to high light of $1600 \mu \mathrm{mol} \mathrm{m} \mathrm{m}^{-2} \mathrm{~s}^{-1}$ were difference across ten sugarcane varieties at 25 DAT of waterlogging, V5 was the highest of $\mathrm{fv} / \mathrm{fm}$ at the end of illumination of $1600 \mu \mathrm{mol} \mathrm{m} \mathrm{m}^{-2} \cdot \mathrm{s}^{-1}$. The trend of decreasing the value of $\mathrm{f}_{\mathrm{v}} / \mathrm{f}_{\mathrm{m}}$ was displayed in Figure 2, in which all of genotype showed decreasing value of $\mathrm{fv} / \mathrm{fm}$ along with addition of illumination/light. Even though, we found that V5 showed increased $f_{v} / f_{m}$ value and it was starting at between 800 to 1600 values of light.
At the 0 DAT value of stomatal conductance $\left(\mathrm{g}_{\mathrm{s}}\right)$ ranged from 544 in V2 to $953 \mathrm{mmol} \mathrm{H} \mathrm{O}^{-2} \mathrm{~m}^{-2} \mathrm{~s}^{-1}$ in $\mathrm{V} 6, \mathrm{~g}_{\mathrm{s}}$ of $\mathrm{V} 6$ had significantly higher than the varieties of V1, V2, V7, and V9 (Fig. 3A), while at the 4 DAT $g_{s}$ ranged from 255 in V5 to $407 \mathrm{mmol} \mathrm{H}_{2} \mathrm{O} \mathrm{m} \mathrm{m}^{-2} \cdot \mathrm{s}^{-1}$ in $\mathrm{V} 9$ even if there were no significantly difference among the varieties (Fig. 3B), at the $7 \mathrm{DAT} \mathrm{g}_{\mathrm{s}}$ ranged from 240 in $\mathrm{KK}$ to $516 \mathrm{mmol}$ $\mathrm{H}_{2} \mathrm{O} \cdot \mathrm{m}^{-2} \cdot \mathrm{s}^{-1}$ in $\mathrm{V} 7, \mathrm{~g}_{\mathrm{s}}$ of $\mathrm{KK}$ was significantly lower than V7 and V9 (Fig. 3C).

Regression analyses between $\mathrm{f}_{\mathrm{v}} / \mathrm{f}_{\mathrm{m}}$ and $\mathrm{g}_{\mathrm{s}}$ showed negative correlation even it was significance at the 4 DAT (Fig. 4A and $B$ ). This result indicated that increasing value of $f_{v} / f_{m}$ had low value of $g_{s}$ under WL. At the end of experiment i.e. 85 DAT, root weight of all varieties were evaluated, it ranged from $130 \mathrm{~g}$ in $\mathrm{V} 1$ to $305 \mathrm{~g}$ in V7 under WL and it ranged from $77 \mathrm{~g}$ in $\mathrm{KK}$ to $133 \mathrm{~g}$ in $\mathrm{V} 6$ under WW. While root volume ranged from $283 \mathrm{ml}$ in $\mathrm{KK}$ to $407 \mathrm{ml}$ in V2 under WL, and it ranged from $77 \mathrm{ml}$ in V3 to $173 \mathrm{ml}$ in V4 under WW. In general, root volumes of WL were significantly higher than WW (Fig. 5). In addition, using Ward's method showed that the varieties that used in this study differentiated to two groups by using stomatal conductance at 7 DAT, panicle number and root volume under treatment of WL data's at 85 DAT (Fig. 6). The first group involved the three out of ten varieties (V1, V3 and $\mathrm{KK}$ ) as the sensitive group to waterlogging and it was showed by low values on growth and physiological traits. While, seven out ten varieties classified as the second group that showed waterlogging tolerance to resistance.

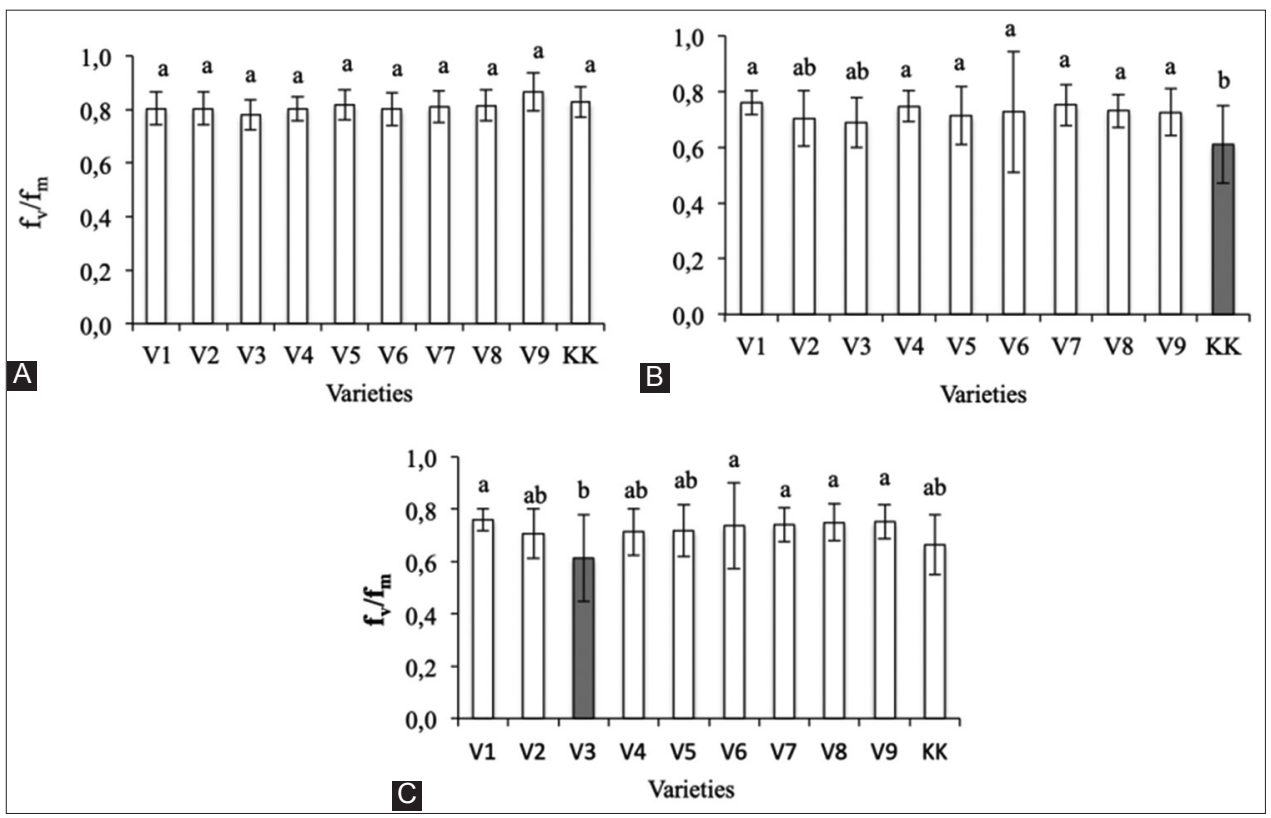

Fig 1. Chlorophyll fluorescence $\left(f_{v} / f_{m}\right)$ of tens sugarcane varieties $(\mathrm{V} 1-\mathrm{V} 9, \mathrm{KK})$, the measurements were conducted under light saturated of $3000 \mu \mathrm{mol} \cdot \mathrm{m}^{-2} \cdot \mathrm{s}^{-1}$ at 0 DAT or before the treatment of waterlogging (A), 4 DAT (B), and 7 DAT (C). Vertical bars indicate SE of five plants. The differences marked with lower case letters are significant at $P<0.05$ (Tukey`s means comparison test). 


\section{DISCUSSION}

Under sub-optimal conditions, plants often show suboptimum response due to environmental limitation. The present of waterlogging and fluctuation light intensity in the field may affect aggravated stress of plants. Once

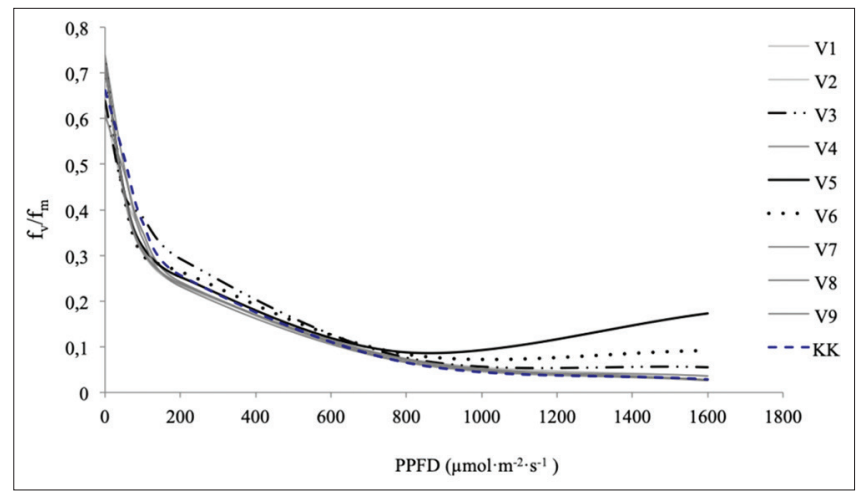

Fig 2. Chlorophyll fluorescence $\left(f_{v} / f_{m}\right)$ of tens sugarcane varieties (V1-V9, KK), the measurements were conducted continuously to two leaves for each varieties under fluctuation light intensity of $0,50,100$, 200,800 , and $1600 \mu \mathrm{mol} \cdot \mathrm{m}^{-2} \cdot \mathrm{s}^{-1}$ at $28 \mathrm{DAT}$. soil pores are filled of water fully, gas diffusion will reduce leading to present hypoxia and or anoxia, increase of stomatal resistant, reduce of photosynthesis and the other responses. These conditions will greatly affect on capacity of plant survive (Parent et al., 2008). The study hypothesized there is a variation of $f_{v} / f_{m}$ and $g_{s}$ response among sugarcane varieties grown under WL and fluctuation light. The response may affect crop performance under such condition. Besides photosynthesis response, $\mathrm{f}_{\mathrm{v}} / \mathrm{f}_{\mathrm{m}}$ could be used as a tool to evaluate plant response (Lazár 1999, 2006) particularly under stresses condition

A clear genetic difference in the response of $f_{v} / f_{m}$ was found in sugarcane genotype of $\mathrm{KK}$ compared to other varieties except in V1 and V3 at the 4 DAT, while, V3 was lower compared to V1 and V6-V9 at the $7 \mathrm{DAT}$, KK is local variety which does not improved, so that physiological traits might not be improved compared to the others varieties. Moreover, the clear differences in $\mathrm{f}_{\mathrm{v}} / \mathrm{f}_{\mathrm{m}}$ were also identified under fluctuation light intensity among varieties of V3, V5 and V6 compared to other varieties at the illumination of $1600 \mu \mathrm{mol} \mathrm{m}^{-2} \cdot \mathrm{s}^{-1}$. The variation of

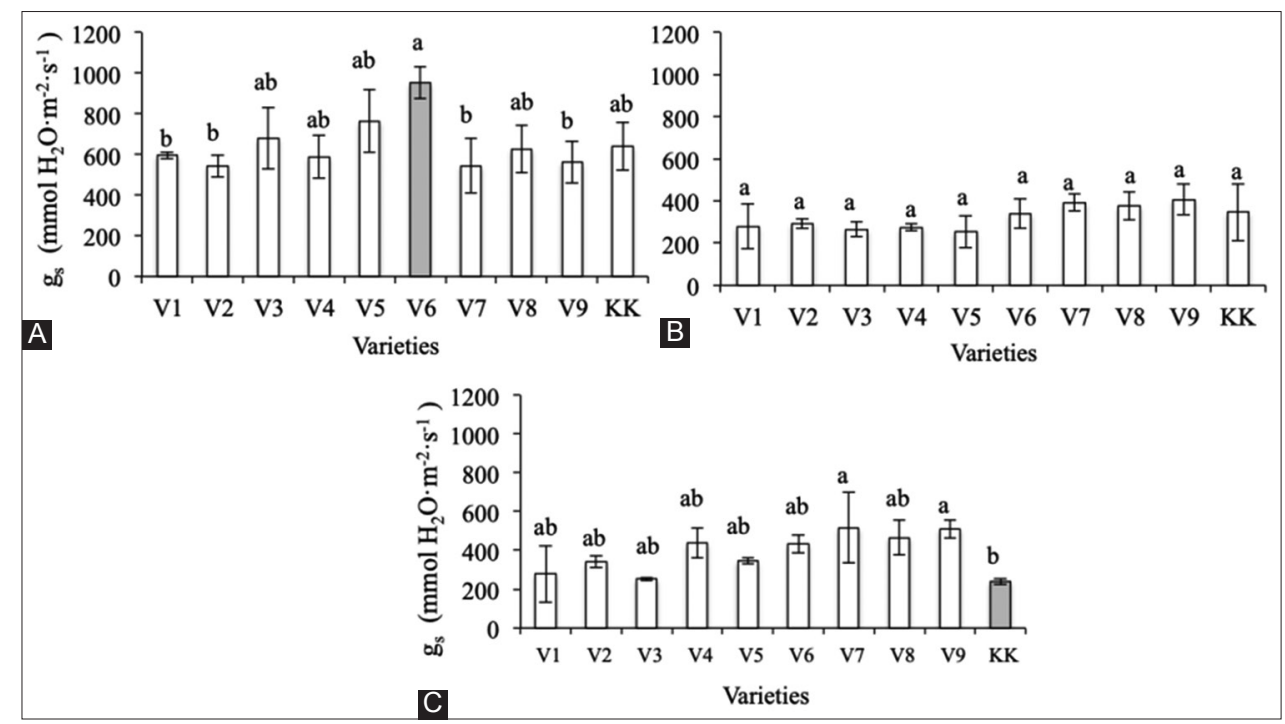

Fig 3. Stomatal conductance $\left(g_{s}\right)$ of tens sugarcane varieties $(\mathrm{V} 1-\mathrm{V} 9, \mathrm{KK})$, the measurements were conducted at 0 DAT or before the treatment of waterlogging (A), 4 DAT (B), and 7 DAT (C). Vertical bars indicate SE of five plants. The differences marked with lower case letters are significant at $P<0.05$ (Tukey`s means comparison test).

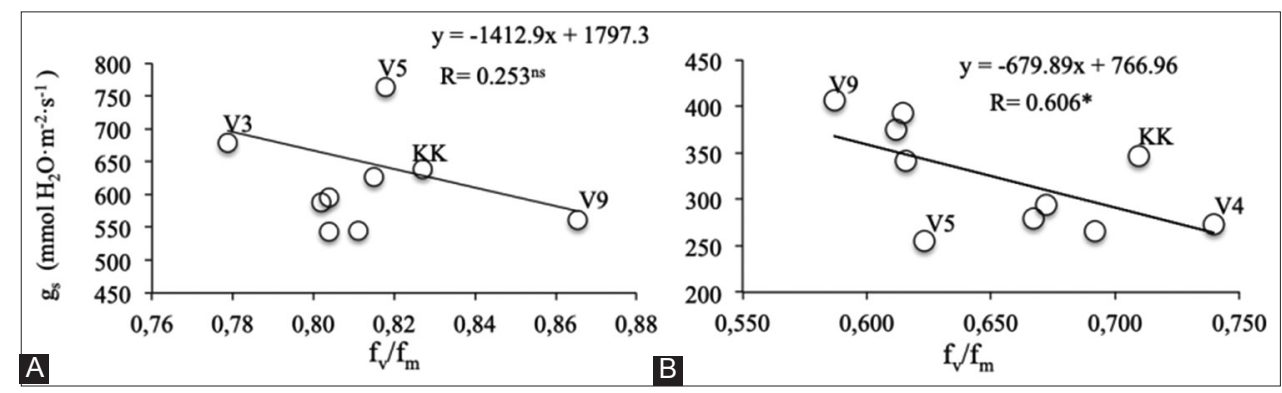

Fig 4. Relationship between $\mathrm{f}_{\mathrm{v}} / \mathrm{f}_{\mathrm{m}}$ and $\mathrm{g}_{\mathrm{s}}$ of tens sugarcane varieties (V1-V9, KK), at 0 DAT or before the treatment of waterlogging (A), and 4 DAT (B). the measurement were conducted to four leaves for each variety. 
$\mathrm{f}_{\mathrm{v}} / \mathrm{f}_{\mathrm{m}}$ under constant and fluctuation light confirmed that some sugarcane varieties had a different characteristic in both condition. These differences in $\mathrm{f}_{\mathrm{v}} / \mathrm{f}_{\mathrm{m}}$ were also difference in $\mathrm{g}_{\mathrm{s}}$, however, the correlation between $\mathrm{f}_{\mathrm{v}} / \mathrm{f}_{\mathrm{m}}$ and $g_{s}$ was negative. These stomatal closures will not associate directly to decreased $\mathrm{f}_{\mathrm{v}} / \mathrm{f}_{\mathrm{m}}$ or photosynthetic efficiency, it will depend on internal $\mathrm{CO}_{2}$ in the leaf (Lawson et al. 2002; Baker \& Rosenqvist, 2004). It is well known that $g_{s}$ and photosynthesis under constant light have a positive correlation where high photosynthetic value is always followed by high in $\mathrm{g}_{\mathrm{s}}$ (Wong et al. 1979; Farquhar \& Sharkey 1982). Characteristic of the $g_{s}$ under constant light is similar to that of variety of $\mathrm{V} 7$ that showed significantly higher in $g_{s}$ and $f_{v} / f_{m}$ at $7 D A T$, while the $f_{v} / f_{m}$ of $V 7$ was not significant higher under fluctuation light intensity. It might be difference mechanism of $f_{v} / f_{m}$ under both condition of light. Like $g_{s}$ response under fluctuation light was not limiting factor of photosynthesis or may less (Soleh et al., 2017; Knapp \& Smith, 1989) or under mild drought stresses such demonstrated in Apple (Massacci \& Jones, 1990).

Stomatal closure is also related to other external signal such as $\mathrm{CO}_{2}$ concentration, humidity, temperature and absisic acid (Lawson, 2009). It is our best knowledge that this is another study reporting natural variation of $\mathrm{f}_{\mathrm{v}} / \mathrm{f}_{\mathrm{m}}$ within single species under abiotic stress, apart from natural variation of photosynthetic induction response of soybeans (Soleh et al., 2016). Abiotic stresses such as waterlogging and light fluctuation had shown the difference in $\mathrm{f}_{\mathrm{v}} / \mathrm{f}_{\mathrm{m}}$ within varieties. It seems to be possible that difference in $\mathrm{f}_{\mathrm{v}} / \mathrm{f}_{\mathrm{m}}$ and $\mathrm{g}_{\mathrm{s}}$ within varieties due to external signal such as absisic acid that might be affected on stomatal closure due to lack of $\mathrm{O}_{2}$ then it led to decreased in internal $\mathrm{CO}_{2}$. Another mechanism of plants to survive under waterlogging stress is by growing more of adventitious roots and developing more aerenchyma tissue to fix $\mathrm{O}_{2}$ (Gomathi et al., 2015; Nishiuchi et al., 2012). In this study, all varieties of sugarcane grown under WL had shown higher in root weight and volume than those varieties grown under WW (Fig. 5). In the same figure, variety that had higher in $\mathrm{f}_{\mathrm{v}} / \mathrm{f}_{\mathrm{m}}$ was higher in root volume as well (i.e variety of V7), it is possible to develop improved waterlogging tolerance is by improving better in $\mathrm{f}_{\mathrm{v}} / \mathrm{f}_{\mathrm{m}}$ responses beside another traits. The differentiation among varieties in adaptive traits was showed by dendogram. The result indicated that one group was more sensitive to treatment and this treatment could be used for screening in breeding program of sugarcane. The genotype V1, V3 and KK were the sensitive varieties (Fig. 6). The dendogram could be used in crops differentiation of adaptive traits such in rice (Muhamad et al., 2016).

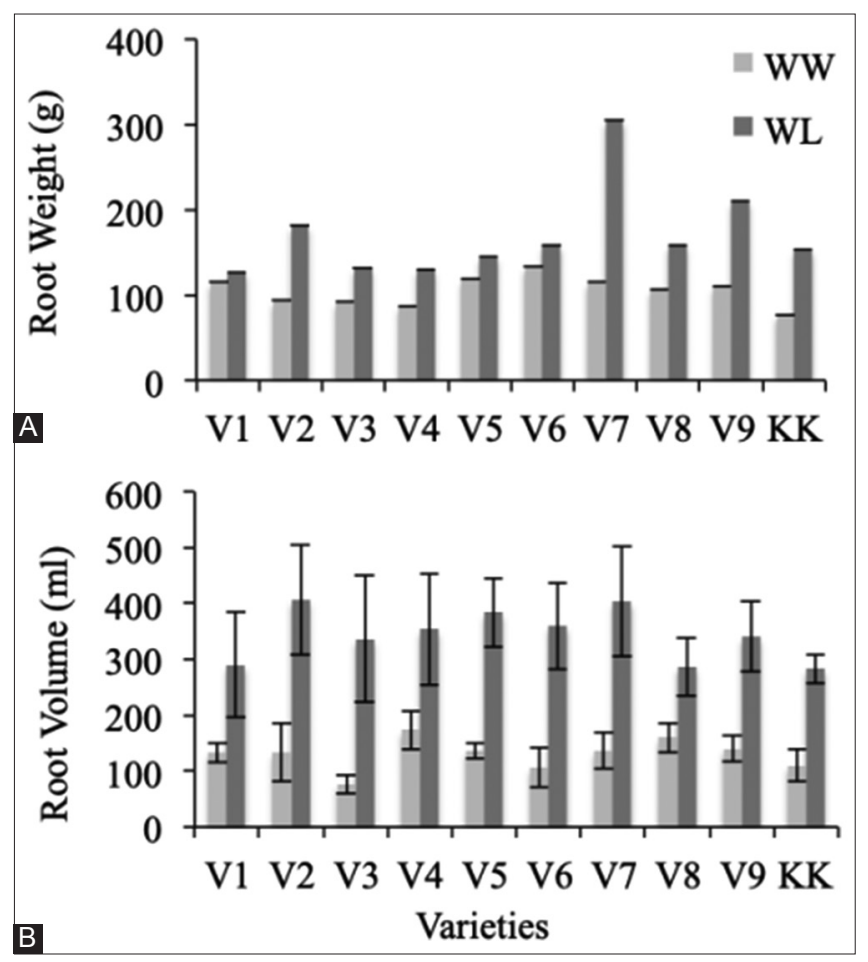

Fig 5. Root weight (A) and volume (B) of tens sugarcane varieties (V1-V9, KK), at 85 DAT. The measurements were conducted to four leaves for each variety. Vertical bars indicate SE of five plants.

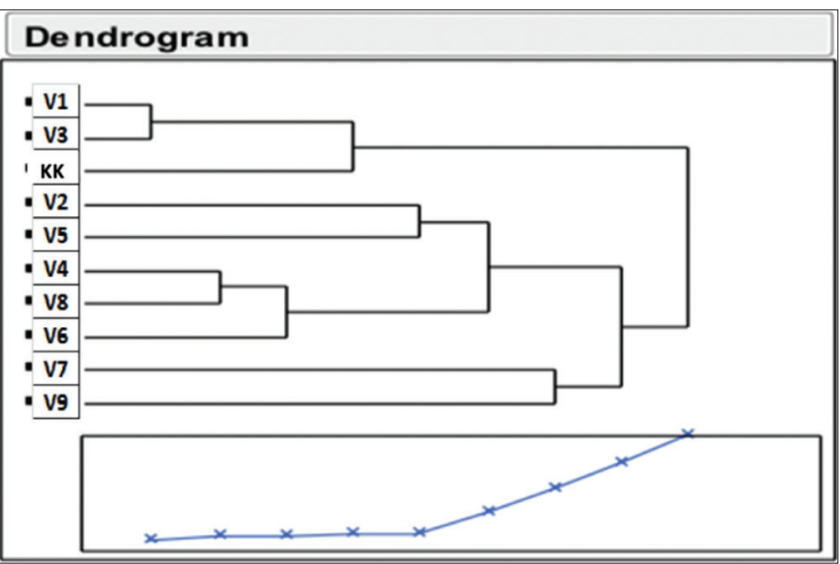

Fig 6. Dendogram based on tens sugarcane varieties (V1-V9, KK) grown under waterlogging (WL) using $g_{s}$ at 7 DAT, panicle number and root volume data's at 85 DAT by ward's method.

In conclusion, we reported genetic difference of $f_{v} / f_{m}$ on some sugarcane varieties grown under waterlogging and fluctuation light intensity. The difference is might be modulated by difference response of $g_{s}$ particularly under constant light condition, while under fluctuation light, there might be modulated by another response such as carboxylase capacity (Soleh et al., 2016). Improving sugarcanes traits under abiotic stress i.e. waterlogging should be considered to improve chlorophyll fluorescence response and stomatal conductance for improving dried matter production. 


\section{REFERENCES}

Araki, H., A. M. Hossain and T. Takahashi. 2012. Waterlogging and hypoxia have permanent effects on wheat root growth and respiration. J. Agron. Crop Sci. 198: 264-275.

Baker, N. R. and E. Rosenqvist. 2004. Applications of chlorophyll fluorescence can improve crop production strategies: An examination of future possibilities. J. Exp. Bot. 55: 1607-1621

Chunthaburee, S., A. Dongsansuk, J. Sanitchon, W. Pattanagul and P. Theerakulpisut. 2016. Physiological and biochemical parameters for evaluation and clustering of rice cultivars differing in salt tolerance at seedling stage. Saudi J. Biol. Sciences. 23(4): 467-477.

Davies, M. S. and G. C. Hillman. 1988. Effects of soil flooding on growth and grain yield of populations of tetraploïd and hexaploïd species of wheat. Ann. Bot. 62: 597-604.

Dickin, E. and D. Wright. 2008. The effects of winter waterlogging and summer drought on the growth and yield of winter wheat (Triticum aestivum I.). Eur. J. Agron. 28: 234-244.

Else, M. A., D. Coupland, L. Dutton and MB. Jackson. 2001. Decreased root hydraulic conductivity reduces leaf water potential, initiates stomatal closure and slows leaf expansion in flooded plants of castor oil (Ricinus communis) despite diminished delivery of ABA from the roots to shoots in xylem sap. Physiol. Plant. 111: 46-54.

Farquhar, G. D. and T. D. Sharkey. 1982. Stomatal conductance and photosynthesis. Annu. Rev. Plant Physiol. 33: 317-345.

Gomathi, R., P. N. Gururaja, K. Chandran and A. Selvi. 2015. Adaptive responses of sugarcane to waterlogging stress: An overview. Sugar Tech. 17: 325-338.

Harrington, J. T., J. G. Mexal and JT. Fisher. 1994. Volume displacement provides a quick and accurate way to quantify new root production. Tree Plant. Notes. 45: 121-124.

Huang, B., J. W. Johnson, S. Nesmith and D. C. Bridges. 1994. Growth, physiological and anatomical responses of two wheat 656 varieties to waterlogging and nutrient supply. J. Exp. Bot. 45: 193-202.

IPCC. 2014. Climate Change 2014. Impacts, Adaptation, Vulnerability. Available from: http://www.ipcc.ch.

Kitajima, M. and W. L. Butler. 1975. Quenching of chlorophyll fluorescence and primary photochemistry in chloroplasts by dibromothymoquinone. Acta Biochim. Biophys. 376: 105-115.

Knapp, A. K. and W.K. Smith. 1989. Influence of growth form on ecophysiological responses to variable sunlight in subalpine plants. Ecology. 70: 1069-1082.

Kozlowski, T. T. and S. G. Pallardy. 1984. Effects of flooding on metabolism. In: T. T. Kozlowski (Ed.), Flooding and Plant Growth, Academic Press, Orlando, FL, pp. 165-193.

Ksas, B., B. Noëlle, A. Chevalier and M. Havaux. 2015. Plant tolerance to excess light energy and photooxidative damage relies on plastoquinone biosynthesis. Sci. Rep. 5: 10919.

Lawlor, D. W., and G. Cornic. 2002. Photosynthetic carbon assimilation and associated metabolism in relation to water deficits in higher plants. Plant Cell Environ. 25: 275-294.

Lawson, T. 2009. Guard cell photosynthesis and stomatal function. New Phytol. 181: 13-34.
Lawson, T., K. Oxborough, J. I. L. Morison and N. R. Baker. 2002. Responses of photosynthetic electron transport in stomatal guard cells and mesophyll cells in intact leaves to light, $\mathrm{CO}_{2}$ and humidity. Plant Physiol. 128: 1-11.

Lazár, D. 2006. The polyphasic chlorophyll a fluorescence rise measured under high intensity of exciting light. Funct. Plant Biol. 33: 9-30.

Lazar, D. 1999. Chlorophyll A fluorescence induction. Biochim. Biophys. Acta. 1412: 1-28.

Massacci, A. and H. G. Jones. 1990. Use of simultaneous analysis of gas exchange and chlorophyll fluorescence quenching for analysing the effects of water stress on photosynthesis in apple leaves. Trees. 4: 1-8.

Maxwell, K. and G. N. Johnson. 2000. Chlorophyllfluorescence a practical guide. J. Exp. Bot. 51: 659-668.

McAusland, L., S. Vialet-Chabrand, P. Davey, N. R. Baker, O. Brendel and T. Lawson. 2016 Effects of kinetics of light-induced stomatal responses on photosynthesis and water-use efficiency. New Phytol. 211: 1209-1220.

Muhamad, K., K. Ebana, S. Fukuoka and K. Okuno. 2016. Genetic relationships among improved varieties of rice (Oryza sativa L.) in Indonesia over the last 60 years as revealed by morphological traits and DNA markers. Genet. Resour. Crop Evol. 64: 701-715.

Nishiuchi, S., T. Yamauchi, H. Takahashi, L. Kotula and M. Nakazono. 2012. Mechanisms for coping with submergence and waterlogging in rice. Rice. 5: 2.

Parent, C., N. Capelli and J. Dat. 2008. Reactive oxygen species, stress and cell death in plants. C. R. Biol. 331: 255-261.

Silva, M., A. De, J. L. Jifon, J. A. G. Silva, D. A. Santos, C. M. Dos and V. Sharma. 2014. Relationships between physiological traits and productivity of sugarcane in response to water deficit. J. Agric. Sci. 152: 104-118.

Singels, A., M. Van Den Berg, M. A. Smit, M. R. Jones and R. Van Antwerpen. 2010. Modeling water uptake, growth and sucrose accumulation of sugarcane subjected to water stress. Field Crops Res. 117: 59-69.

Slattery, R. A., B. J. Walker, A. P. M. Weber, D. R. Ort. 2018. The impacts of fluctuating light on crop performance. Plant Physiol. 176: $990-1003$

Soleh, A. M., T. Yu, N. Yuko, I. Yu, N. Keiichiro, F. Yasuko, L. P. Stephen and S. Tatsuhiko. 2016. Factors underlying genotypic differences in the induction of photosynthesis in soybean (Glycine max L.) Merr. Plant Cell Environ. 69: 685-693.

Soleh, M. A., Y. Tanaka, S. Y. Kim, S. C. Huber and T. Shiraiwa. 2017. Identification oflarge variation in the photosynthetic induction response among 37 soybean (Glycine max L.) Merr. Varieties that is not correlated with steady-state photosynthetic capacity. Photosynth. Res. 131: 305-315.

Wong, S. C., I. R. Cowan and G. D. Farquhar. 1979. Stomatal conductance correlates with photosynthetic capacity. Nature. 282: 424-426.

Zhou, J., Q. Anguo, Z. Yi-Chuan, W. Shu-Wen and Q. Pei. 2012. Adventitious root growth and relative physiological responses to waterlogging in the seedlings of seashore mallow (Kosteletzkya virginica), a biodiesel plant. Aust. J. Crop Sci. 6: 73-80. 